\title{
The perspective of caffeine and caffeine derived compounds in therapy
}

\author{
Pohanka $\mathrm{M}^{1,2}$ \\ Faculty of Military Health Sciences, University of Defence, Hradec Kralove, Czech Republic. \\ miroslav.pohanka@gmail.com
}

\begin{abstract}
Caffeine (1,3,7-trimethylxanthine) is a plant secondary metabolite with a significant impact on multiple processes and regulatory pathways in the body. Though major part of the population meets caffeine via coffee, tea or chocolate, it has also an important role in pharmacology and it is used as a supplementary substance in medicaments. Currently, the ability of caffeine to ameliorate some neurodegenerative disorders is proved in some studies. This review describes basic data about caffeine including toxicity, pharmacokinetics, biological mechanism of the action, and metabolism. Beside this, promising applications of caffeine, new medicaments and derivatives are discussed. Relevant papers and inventions are depicted in the manuscript.

Caffeine is a pharmacologically promising substance that deserves big consideration in the current research and development. The compound has several reasons to be an object of scientific interest and to be used for pharmacology purposes. Despite an extensive research for a long time, no significantly negative effects on human health were proved hence caffeine can be considered as a completely safe compound. The recent data about amelioration of neurodegenerative and other disorders are promising and deserving more work on the issue. ARTICLE HIGHLIGHTS

Caffeine is a purine alkaloid from plants and it has a broad use in current pharmacology.

Caffeine is a competitive antagonist of neurotransmitter adenosine on adenosine receptors.

The substance is added as a supplementary to drugs and food.

Besides interfering on adenosine receptors, caffeine interacts with acetylcholinesterase, monoamine oxidase, phosphodiesterase, ryanodine receptors and others.

Current research is devoted to the role of caffeine in neurodegenerative diseases and immunity alteration.

New chemical compounds based on caffeine moiety are prepared(Tab. 4, Fig. 6, Ref. 149). Text in PDF www.elis.sk. KEY WORDS: caffeine, Alzheimer disease, Parkinson disease, immunity, adenosine, GABA, dopamine, theophylline, theobromine.
\end{abstract}

\section{Introduction}

Purine alkaloids have a significant role in pharmacology and food chemistry. Caffeine, 1,3,7-trimethylxanthine, is probably one of the most relevant purine alkaloids in this point of view. Coffee, a caffeine containing beverage prepared from plants Coffeaarabica and C. canephora, have been known since medieval time (1). Caffeine can be found in tea plants like Camellia sinensis, so humans probably use caffeine containing beverages for more than four thousand yearssince drinking of tea was documented in ancient times(2-4).

${ }^{1}$ Faculty of Military Health Sciences, University of Defence, Hradec Kralove, Czech Republic, and ${ }^{2}$ Department of Geology and Pedology, Mendel University in Brno, Brno, Czech Republic

Address for correspondence: M. Pohanka, MD, Faculty of Military Health Sciences, University of Defence, Trebesska 1575, CZ-500 01 Hradec Kralove, Czech Republic.

Acknowledgements: The Ministry of Education, Youth and Sports of the Czech Republic is gratefully acknowledged for project LH11023 and A long-term organization development plan 1011 (Faculty of Military Health Sciences, University of Defence, Czech Republic).
Production and sale of coffee seeds belongs to the significant income of developing countries. Theexpected economic profit from the agriculture of caffeine plants is around 20,000 USD per year and hectare (5). Planting C. sinensis for tea leafs production have similar importance in the agriculture as plantingcaffeine plants(6). Caffeine has an eminent role in pharmacology as well. The fact is eminent from the citations and the following text (7-9). Pure caffeine can be quite easily obtained by an extraction from coffee seeds or tea leafs $(10,11)$ and chemical synthesis is applicable as well $(12,13)$.

Because caffeine exerts low toxicity combined with relevant biological effects, it is an object of interest for many investigators. Caffeine is a stimulating compound acting via adenosine receptors; however, the other neural pathways can be also involved in caffeine effect. Broad implication and a promising use of caffeine can be learned from the current literature. In this review, caffeine is introduced as a simple alkaloid able to modulate many pathways in the body. However, major effort was given to discussion about caffeine's pharmacological importance and the opportunity to use caffeine in combination with the other biologically active compounds or use of the caffeine derivatives. Targets for caffeine, its metabolism and toxicology are 
discussed here as well and the expected directions of next research are proposed.

\section{Biological synthesis, metabolism and pharmacokinetics of caffeine}

Caffeine is a purine alkaloid and the anabolism of caffeine has steps identical or similar tothe anabolism of many other alkaloids.

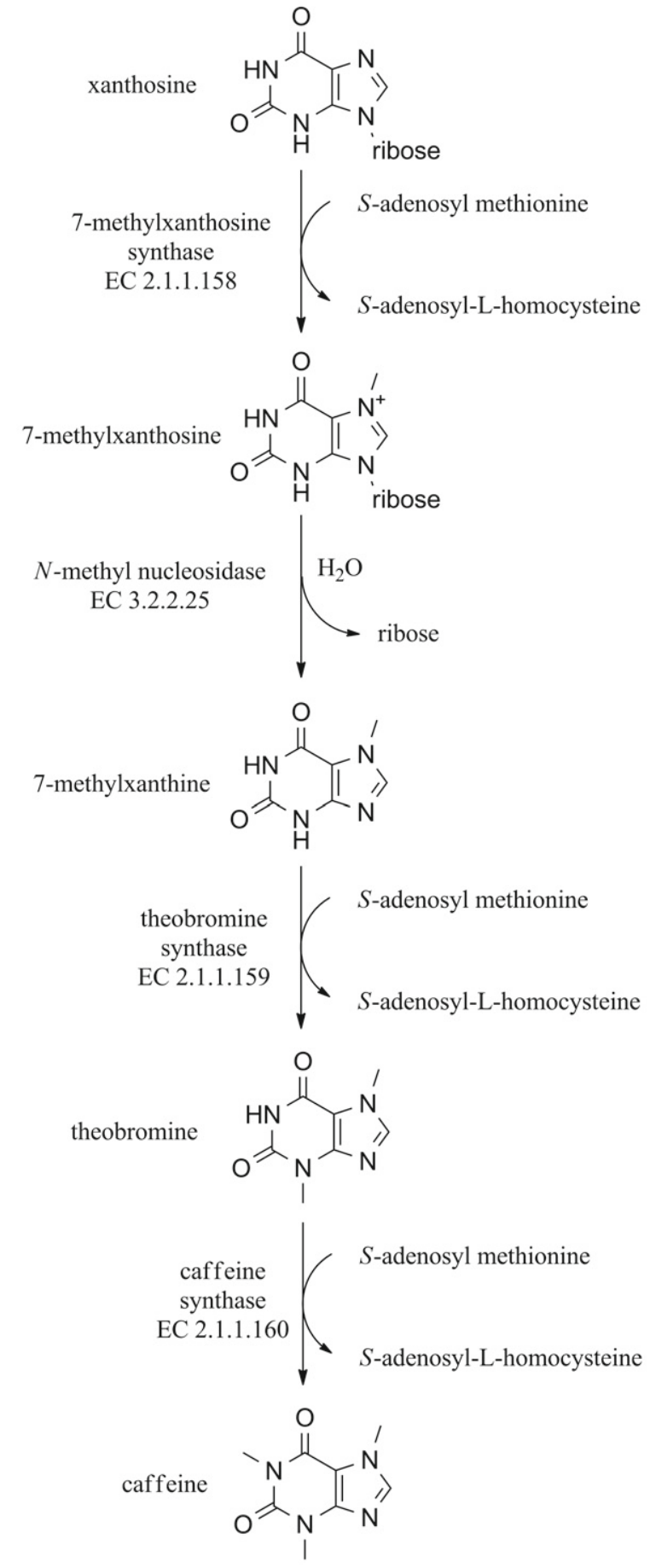

Fig. 1.Synthesis of caffeine in the plants.

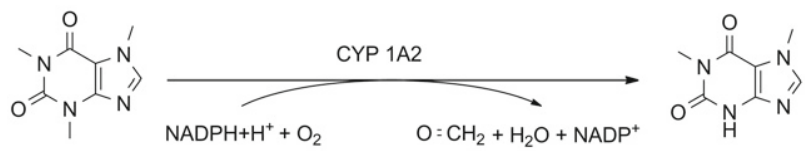

Fig. 2.Caffeine demethylation to paraxanthine.

Pathway for caffeine remained unrevealed for a long time and some doubts about caffeine precursor in plants were claimed until resolving the issue in the recent years (14). Dominant pathway of caffeine production in the plant is based on consequent methylation inxanthosine, 7 -methylxanthine and theobromine $(15,16)$, and hydrolysis of ribose from 7-methylxanthosine by N-methyl nucleosidase (EC 3.2.2.25) (17,18). S-adenosyl methionine is a source for implementation of the methyl moiety into the intermediates and it is also a co-substrate for the involved enzymes 7-methylxanthiosine synthase (EC 2.1.1.158), theobromine synthase (EC 3.2.2.25), and caffeine synthase (EC 2.1.1.160) (19). Caffeine biosynthesis pathway is summarized in the Figure 1.

Typical intake of caffeine is peroraland drinking of caffeine containing beverages or food is probably the most relevant in the current population. Intake of caffeine in drugs is another significant income of the compound. The peak concentration of caffeine in plasma is reached in 120-180 minutes after its intake; however, fasted people can have reached caffeine peak in plasma within 60 minutes as proved on male volunteers (20). The half time of caffeine in human plasma is $5.7 \mathrm{~h}$ and the clearance is $0.74 \mathrm{ml} /$ $\min \times \operatorname{kg}(21)$. However, the authors proved that the half time can be dramatically increased up to nearly 15 hours when liver function is impaired e.g. due to cirrhosis. It should be emphasized that caffeine is metabolized in the liver as mentioned further. The metabolic products are biologically active as well and their effect is very close to the effect of caffeine(22). In literature, another half time for caffeine can be found. In an example, half time $4.3 \mathrm{~h}$ for a healthy population and even $3.0 \mathrm{~h}$ for smokers were reported by Seng and co-workers (23).

In mammals,caffeine is metabolized by cytochromes $\mathrm{P} 450$ via oxidative demethylation into paraxanthine, theobromine and theofiline. The methyl moiety is split from the structure as formaldehyde (24).The most relevant pathway for caffeine detoxification is based on oxidative demethylation by $\mathrm{P} 450$ isotype CYP1A2 to paraxanthine $(25,26)$. Activity of CYP $1 \mathrm{~A} 2$ is distinct in the population and formssuch as $1 \mathrm{~A}, 1 \mathrm{~B}, 1 \mathrm{C}$, and $1 \mathrm{~F}$ can be foundamonghumans; however, the ability to oxidize xanthine alkaloids is not significantly different $(27,28)$. The oxidative demethylation of caffeine to paraxanthine is depicted in the Figure 2. Beside CYP 1A2, other isotypes can be also involved in the oxidation of caffeine. Namely, CYP 2C8, CYP 2C9, CYP 3A4 in humans and 2C11 or $3 \mathrm{~A} 2$ in rats play a role in the metabolism (29). As aforementioned inthe work byMesaros and co-workers, the metabolism of caffeine is significantly depressed inliver when hepatitis occurs(21). On the other hand, caffeine plausibly reduces inflammatory processes inliver during the hepatitis $(30,31)$. Though beneficial effect of caffeine in patients who suffered from hepatitis can be learned from the quoted papers, more work on the issue is needed to make conclusions and to understand mechanism of the effect. Involve- 
ment in regulation of immunity response can be mentioned as an hypothesis how caffeine can be implicated in change of the diseases progression (32).

\section{Interaction of caffeine with receptors and other target struc- tures}

Caffeine has the major pathway in the body where it takes its biological effect. It is a competitive antagonist of neurotransmitter adenosine on adenosine receptors. Adenosine is an important neurotransmitter interacting with the adenosine receptors (33). There are four known types of adenosine receptors designated as $A_{1}, A_{2 A}, A_{2 B}$, and $A_{3}$ being coupled to $G$ protein and responsiblefor e.g. regulation of the heart rate, vasodilatation, bronchospasm, smooth muscle contraction, inhibition of neutrophils degranulation with an effect on adjacent immunity and some others (34-36). Themental sedation because of receptor $\mathrm{A}_{2 \mathrm{~A}}$ and bradycardia via receptors $A_{1}$ as well as $A_{3}$ are typical manifestations of agonism and the oppose effect is evoked just by caffeine $(37,38)$. The $\mathrm{A}_{3} \mathrm{i}-$ sotype is also involved in the regulation of neutrophils and its degranulation $(39,40)$. From the mentioned receptors, the isotype $\mathrm{A}_{2 \mathrm{~A}}$ is dominantly located in central nervous system, especially in the extrastriatal forebrain, where it acts on behavior and mental excitation in a link to dopamine, glutamate and brain derived neurotrophic factor signaling (41-44). In recent time, neuroprotective effects of antagonist on $\mathrm{A}_{2 \mathrm{~A}}$ receptors after cerebral ischemia were discovered (45).Cerebral ischemia is considered as a consequence and maybe the primary reason for some neuropathologies with unknown etiology, antagonism on the receptors by caffeine or any other compound would have significant pharmacological sense.Beside the aforementioned effects, adenosine is responsible for bronchospasm, whichis regulated through $\mathrm{A}_{2 \mathrm{~B}}$ receptors (46). In the bronchus, caffeine can suppress bronchospasm and even significantly ameliorate bronchoconstriction just by antagonizing of the $A_{2 B}(47,48)$. When we take a global look at the adenosine receptors, it should be emphasized that other xanthines structurally close to caffeine are also antagonists on adenosine receptors $(49,50)$. Theophylline as an example $(51)$.

Beside the adenosine receptors, caffeine actsalso on other neurotransmission systems, but the effect is significantly lower and probably is a consequence of the effect on adenosine. Imbalances in acetylcholine, epinephrine, norepinephrine, serotonin, dopa- mine and glutamate after caffeine administration are described in the current literature(52-56). On the other hand, caffeine can have targets in the pathways since most of the data proved in laboratory on animals have not been studied on an in vitro model. Detailed data about the role of caffeine in the pathways are scarred and conclusion has to be inferred fromavailable sources. The idea of multi-target effect of caffeine is confirmed by some works where the targets were revealed.

The effect on dopamine neurons can be caused by a reversible inhibition of monoamine oxidase, which seems to havesmall scale, but significant enoughto be demonstrated in the body (57). This inhibition can protect from the oxidation of epinephrine, norepinephrine, serotonin, and dopamine, hence research on the issue hasa pharmacological importance and enhance the current knowledge about caffeine(58). Cholinergic system is altered by caffeine via inhibition of the enzyme acetylcholinesterase. Caffeine acts as a non-competitive inhibitor of the enzyme and protect thus from splitting of neurotransmitter acetylcholine, which may results in a higher accessibility of acetylcholine on acetylcholine receptors(32,59). Cholinergic system is an important part of the both central and peripheral nervous system with wide functions(60-62). Cholinesterases are widely presented in the blood as well (63). A link to the immunity system via cholinergic system by cholinergic anti-inflammatory pathway can be another target of caffeine (32). Besides the aforementioned extracellular signaling, caffeine has also its targets in intracellular signaling pathways. Intracellular messengerscAMP and cGMP have a protracted time for signaling in the presence of caffeine because of the reversible inhibition of phosphodiesterase $(64,65)$. The second effect of caffeine on intracellular pathways is mediated through ryanodine receptors located on sarcoplasmic reticulum and serving asspecific channels for the influx of $\mathrm{Ca}^{2+}(66-70)$. Caffeine is a full agonist on the ryanodine receptors and it forces $\mathrm{Ca}^{2+}$ transient (71-73) alsoit is used as controlsin experiments where $\mathrm{Ca}^{2+}$ should be transferred to cells (74). It has also an impact on the genetic information via poly(ADP-ribose)polymerase-1 that is activated and responsible for DNA strand breaks repair. Caffeine acts as an inhibitor of the enzyme (75). The effect results not only in an alteration in DNA repair,but also in cell cycle control $(76,77)$. The meaning of caffeine ability to inhibit poly(ADP-ribose)polymerase is not fully explored. Though some apprehensions that caffeine would initiate cancer were stated in the past, clinical tests either did notconfirm

Tab.1.Molecular targets of caffeine.

\begin{tabular}{llll}
\hline Target structure & Role of the target structure & Effect of caffeine & References \\
\hline Acetylcholinesterase & it splits neurotransmitter acetylcholine & non-competitive inhibitor of acetylcholinesterase & $(32,59-62)$ \\
\hline Adenosine receptors & $\begin{array}{l}\text { G protein coupled receptor mostly implicated } \\
\text { in sedation (bradycardia, suppression of mental } \\
\text { excitation etc.) }\end{array}$ & competitive antagonist on adenosine receptors & $(37-44,47,48)$ \\
\hline Monoamine oxidase & $\begin{array}{l}\text { oxidizes epinephrine, norepinephrine, sero- } \\
\text { tonin, and dopamine }\end{array}$ & reversible monoamine oxidase & \\
\hline Phosphodiesterase & $\begin{array}{l}\text { the enzyme hydrolyzes secondary intracellular } \\
\text { messengers cAMP and cGMP }\end{array}$ & reversible inhibitor of phosphodiesterase & \\
\hline Poly(ADP-ribose)polymerase & DNA repair, apoptosis & reversible inhibitor of poly(ADP-ribose)polymerase & $(75-77)$ \\
\hline Ryanodine receptor & $\mathrm{Ca}^{2+}$ channel on sarcoplasmic reticulum & agonist of ryanodine receptor & $(66-73)$ \\
\hline
\end{tabular}


Tab.2.Toxicity data about caffeine.

\begin{tabular}{|c|c|c|}
\hline Description & Value & References \\
\hline Manifestation of poisoning & $129 \mu \mathrm{mol} / 1$ (plasma level) & $(81,82)$ \\
\hline Peak plasma concentration after taking $100 \mathrm{mg}$ of caffeine & $10.3 \mu \mathrm{mol} / 1(\mathrm{men}) / 18.5 \mu \mathrm{mol} / 1$ (women $)$ & $(25)$ \\
\hline Rat $\left(\mathrm{LD}_{50}\right)$ & $155 \mathrm{mg} / \mathrm{kg}$ & $(86)$ \\
\hline $\operatorname{Dog}\left(\mathrm{LD}_{50}\right)$ & $140 \mathrm{mg} /$ & $(87)$ \\
\hline Water flea Ceriodaphniadubia $\left(\mathrm{LC}_{50}\right)$ & $60 \mathrm{mg} / \mathrm{l}$ & $(88)$ \\
\hline Fathead minnow fish Pimephalespromelas $\left(\mathrm{LC}_{50}\right)$ & $100 \mathrm{mg} / 1$ & $(88)$ \\
\hline Nematoceran flies Chironomusdilutus $\left(\mathrm{LC}_{50}\right)$ & $1230 \mathrm{mg} / 1$ & $(88)$ \\
\hline
\end{tabular}

$\mathrm{LD}_{50}-$ median lethal dose; $\mathrm{LC}_{50}-$ median lethal concentration

or even excluded the hypothesis (78). Contrary, some anti-cancer effects of caffeine are mentioned in the current literature $(79,80)$. The whole issue deserves a deeper insight and perhapsitwill be target of an extensive clinical search.

Though it can appear that only minor effect of caffeine is mediated through adenosine receptors when considered the aforementioned works, the contrary is true. Affinity of caffeine to the other targets is typically lower than the affinity to adenosine receptors, so the biological role of the other targets should be considered carefully and needs further effort to be understood how significant it is in real conditions. The signaling pathways mentioned in the text are summarized in the Table 1.

\section{Caffeine toxicity}

Toxicity of caffeine is low and there are no or minimal adverse effects when caffeine is taken by a beverage or food. It is assumed that manifestation of caffeine toxicity appears when its plasmatic concentration reaches $129 \mu \mathrm{mol} / \mathrm{l}$ (i.e. $25 \mathrm{mg} / \mathrm{kg}$ in mass scale) as demonstrated on a case report $(81,82)$. Overdosing by caffeine is not a common phenomenon and it can occur due towrong application of food supplements or drugs containing caffeine. Abusing of caffeine via food or beverages is not known in the current medicine and stimulating pills or substances for fitness are the more treating forms of caffeine in this point of view. Banerjee and co-workers have analyzed the cases of fatal caffeine intoxication and stated that the average postmortem concentration of caffeine was 140 $\mathrm{mg} / \mathrm{l}(83)$. The intoxicated people died due tocardiac arrhythmias, seizures can also occur in the overdosed. Abusing of caffeine can be clearly demonstrated on a case report described by Jabbar and Hanly(84). They reported a case of a 39 year old man overdosed by $12 \mathrm{~g}$ of pure caffeine. As proved by autopsy, the man had blood caffeine level $350 \mathrm{mg} / \mathrm{l}$.

Safety of caffeine containing beverages and food can be inferred from the following example. Yubero-Lahoz and co-workers tested the concentration of caffeine in plasma of men and women after drinking a cup of coffee with $100 \mathrm{mg}$ of caffeine (25). The male subjects exerted caffeine peak concentration in plasma $2.0 \mathrm{mg} / 1(10.3 \mu \mathrm{mol} / \mathrm{l})$ while the female subjects $3.6 \mathrm{mg} / 1$ (18.5 $\mu \mathrm{mol} / \mathrm{l})$. The amount of caffeine in beverages can differ fromeach other because ofthetechnological and individual reasons. Inliterature, concentration of caffeine $120.5 \mathrm{mg} / \mathrm{l}$ for green tea, $149.5 \mathrm{mg} / \mathrm{l}$ for black tea, $267.5 \mathrm{mg} / 1$ for coffee, $94.1 \mathrm{mg} / \mathrm{l}$ for Coca Cola and $55.5 \mathrm{mg} / \mathrm{l}$ for Pepsi can be found (85). When considered the text above, it is clear that the current beverages have too low concen- tration of caffeine to make serious overdosing. A man should take tens of cups of coffee at a blow to reach plasmatic concentration of caffeine so high to threaten his life.

Caffeine seems to be harmless compound since the median lethal doses $\left(\mathrm{LD}_{50}\right)$ for caffeine are high. In examples, $\mathrm{LD}_{50}$ is $155 \mathrm{mg} / \mathrm{kg}$ for rats (86) and $140 \mathrm{mg} / \mathrm{kg}$ for German shepherd dogs (87).Quite a high range of median lethal concentration $\left(\mathrm{LC}_{50}\right)$ is reported for water organisms but the water organisms exert also considerable tolerance to caffeine. Water flea (Ceriodaphniadubia) exerted $\mathrm{LC}_{50} 60 \mathrm{mg} / \mathrm{l}$, fathead minnow fish (Pimephalespromelas) $100 \mathrm{mg} / \mathrm{l}$, and nematoceran flies Chironomusdilutus $1230 \mathrm{mg} / \mathrm{l}$ in one experiment (88). On the other hand, people should be aware of some adverse effects that precede toxicity manifestation (see later). Toxicological data for caffeine are summarized in the Table 2.

Compared to adults, children are more sensitive to caffeine and overdosing can arise much early and unforeseen (89).Special caution to caffeine should be given topregnant women and fetus. In an experiment on zebrafish embryos, caffeine significantly modulated their moves during development and the embryos exerted abnormality in skeletal muscles formation (90). Angiogenesis is altered by caffeine in zebrafish model as well (91).Retardation of intrauterine growth and impaired fetal length growth were indicated forWistar rats receiving caffeine $120 \mathrm{mg} / \mathrm{kg}$ in 11-20 gestational days (92). Caffeine can further worsen toxicity to fetus of some other compounds. This fact was approved by e.g. Nikoui and co-workers for clomipramine (93). In humans, fecundability is reduced in women taking more than $300 \mathrm{mg}$ of caffeine perday (94). The other adverse effect including a decline of fetal development isalso expected in humans (95). On the other hand, doses of caffeine under approximately 200 mga day can be considered harmless in pregnancy. Jahanfar and Jaafar demonstrated that a dose of caffeine $182 \mathrm{mg}$ per a day had no effect on birthweight or length of gestation (96).

Some controversies can be found for caffeine and infertility. Some works are concluded by a statement that caffeine has no influence on woman fertility (97), but the conclusions are not identical in other sources (98). Moreover, caffeine is suspected to be implicated in male infertility (99). In a small pilot study, avoiding of risk factors such as alcohol drinking, smoking and coffee intake, was proved to have a positive role on fertility, while abusing the aforementioned leads to fertility impairment(100). When consideringstudies, it is not easy to distinguish what is the cause and what the consequence. The role of caffeine in infertility should be evaluated carefully. Molecular mechanism how caffeine could initiate infertility is not clear as well. Moreover, caffeine addi- 
Tab.3.Basic data about medications containing caffeine.

\begin{tabular}{|c|c|c|}
\hline Effective substances & Purpose & Example of trade names or patents \\
\hline Caffeine & suppression of sleep and fatigue & Enerjets, No Doz, Vivarin \\
\hline Acetylsalicylic acid, caffeine & \multirow{5}{*}{$\begin{array}{l}\text { analgesic, antipyretic and stimulant drug for } \\
\text { amelioratingin e.g. influenza etc. }\end{array}$} & Anacin, Antidol, Atasol, Astone Cap, Calmine, Pain Aid \\
\hline Acetylsalicylic acid, caffeine, codeine & & AC\&C, Painex \\
\hline Paracetamol (acetaminophen), caffeine, codeine & & Atasol, Acet, Corytab, Cotabs, NovoGesic \\
\hline acetylsalicylic acid, butabital, caffeine & & Trianal, Ratio-Tecnal \\
\hline Paracetamol, butabital, caffeine & & Esgic-Plus, Orbivan \\
\hline $\begin{array}{l}\text { Nicotine, tryptophan, phenylalanine, tyrosine and } \\
\text { caffeine }\end{array}$ & pain relieve in migraines & patent CA2826019 A1 (109) \\
\hline $\begin{array}{l}\text { Lecithin organogel, an ethylene oxide-propylene } \\
\text { oxide ethylene oxide triblock copolymer, caffeine, } \\
\text { retinoid, }\end{array}$ & cellulite & patent US 2013/0210840 A1 (113) \\
\hline $\begin{array}{l}\text { yacon (Smallanthussonchifolius) with caffeine and } \\
\text { some vitamins (C, H, B6, D3) and admixtures }\end{array}$ & weight loss & patent CA2747904 A1 (114) \\
\hline
\end{tabular}

tive to semen during in vitro fertilization improves probability of pregnancy (101). This conclusion is in a little contradiction to the clinical tests. More work on the issue should be done prior to make the final conclusion.

\section{The current use of caffeine in pharmacology}

Caffeine is known as a cognitive enhancer. It has no plausible effect on memory or ability to learn except of suppression of fatigue; however, it improves hedonic tone and reduces anxiety when given in a low dose (102). When dose of caffeine is increased, tense arousal, anxiety, nervousness and jitteriness can be expected.Even caffeine neurosis can occur in rare cases of caffeinism (103). It is widely discussed if $r$ caffeine can modulate progression of cognitive decline in patients suffering from neurodegenerative disorders (104). Lower incidence of Alzheimer disease was found in humans who regularly take coffee when compared toones, who have not taken coffee during their lives $(105,106)$. Etiology of Alzheimer disease remains unrevealed hence mechanism of caffeine implication in the disease can be only speculated; on the other hand, beneficial effect of caffeine is considered to be plausibly proved (107). Considering the aforementioned anti-inflammatory effect of caffeine and the fact that neuro-inflammation is considered as either reason or one of Alzheimer disease mechanism, caffeine can take its effect just this way. Surprisingly, no therapy based on caffeine was established for Alzheimer disease. Similar conclusion can be made for Parkinson disease, where caffeine beneficial effect was proved in some studies, but the mechanism remains a mystery (108).

Caffeine is utilized as a drug additive in some medications or as a major substance in drugs for suppression of sleep and fatigue. Pure caffeine is sold in form of tablets with $200 \mathrm{mg}$ of caffeine or lozenge with $75 \mathrm{mg}$ of caffeine. Brand names Enerjets, No Doz and Vivarin can be mentioned as examples of the marketed products. Caffeine is also added to medications for suppression of influenza and similar viral infections manifestation. The medications contain caffeine as a stimulant and an antipyretic and analgesic substance such as acetylsalicylic acid (e.g. Anacin, Antidol, Atasol, Astone Cap, Calmine, Pain Aid) or paracetamol. The an- algetic effect can be further graduated by addition of an opiate, which can result in significant antitussive properties. Codeine in combination with caffeine and either paracetamol (medications Atasol, Acet, Corytab, Cotabs, NovoGesic) or acetylsalicylic acid (AC\&C, Painex) isknown. Similar indication has medicaments where butabitalisis used instead of codeine.Caffeine is added to tablets for pain relieve during migraines. For the migraines, commercial medication Wigraine contains $1 \mathrm{mg}$ of ergotamine tartrate and $100 \mathrm{mg}$ of caffeine per one tablet. An invented medicament containing nicotine, tryptophan, phenylalanine, tyrosine and caffeine would be an improvement tothe current drugs for migraines (109).Caffeine can provide a relieve in post-lumbar puncture headache appearing after lumbar puncture or epidural anesthesia. It is an iatrogenic problem complicating a recovery of patients. Caffeine can be applied and it is very effective inboth prophylaxis and treatment of post-lumbar puncture headache (110-112). Compositions of medicaments containing caffeine and chosen brand names are written in the Table 3.

Besides the currently used drugs, caffeine is intended to be added to new preparations for several reasons. Grasela and coworkers invented a preparation for treating cellulite composedof lecithin organogel, ethylene oxide-propylene oxide ethylene oxide triblock copolymer, caffeine, retinoid, and optionally some vitamins (113).Extract from plant yacon (Smallanthussonchifolius) with caffeine and some vitamins (C, H, B6, D3) and/or other effective substances from disparate plants (e.g. Lyciumbabarum, Malpighiaglabra, Vacciniumcorybosum, Punicagranatum) was invented as a medicament for weight loss(114).

\section{Expected application of caffeine in pharmacology}

Caffeine has a significant use in the medications described in the previous chapter. However, the current use is dominantly based on the addiction of caffeine as a supplementary substance. On the other hand, the current status can change because of the recent findings devoted to a protective effect of caffeine in Alzheimer disease associated pathologies including deposition of amyloid precursor 42 (105). Intake of 3-5 cups of coffee per a day is significantly associated with a lower incidence of Alzheimer disease 
Tab.4.Caffeine effect on diseases where no pharmacologically application of caffeine is known.

\begin{tabular}{lcccc}
\hline Disease & Effect of caffeine & Manifestation of caffeine & Dose \\
\hline Alzheimer disease & positive & later onset and slower progres- & $3-5$ cups of coffee per a day \\
\cline { 1 - 2 } Parkinson disease & positive & sion of the disease & Reference & $(115)$ \\
\hline Huntington's disease & negative & early onset of the disease & $>190 \mathrm{mg}$ per a day \\
\hline
\end{tabular}

(115). Unfortunately, no therapy or prophylaxis based on caffeine application has been established. On the other hand, coffee as a food supplement is accessible and some preparations are invented to be added to food in order to ameliorate the neurodegenerations. As an example, Chu and co-workers invented the mixture containing caffeine and polyphenolic antioxidants that would be used for the purpose useful for facilitating neuroprotection, inhibition of cyclooxygenase 2 or stimulating glucose uptake (116). The authors postulated that crude caffeine containing other biologically active substances exert beneficial effect due to the presence of the noncaffeine components. They proved their postulation on cell lines where cells were plausibly more resistant to an oxidative insult and/or other inflammatory stimuli.

Caffeine is easily accessible in a pure form and there are available patented protocols for caffeine purification from crude mass (117-120). Besides standard routes, caffeine can be delivered by an electronic cigarette (121) or by microparticles for sustained release (122) hence the application is not needed to be limited to pills and solutions. Other mixtures were prepared in order to reduce a side effect of caffeine. Crain and co-workers invented the mixture of caffeine with compounds selectively blocking or inhibiting opioid receptor signaling naltrexone, naloxone, diprenorphine, nalmefene, norbinaltorphimine, neuraminidase inhibitors methylsulfonylmethane, magnesium sulfate, sodium sulfate, chondroitin sulfate, n-acetyl-cyteine, zanamivir, laninamivir, peramivir, oseltamivir and 5,7,4,'-trihydroxy-8-methoxyflavone (123). On the other hand, it is questionableif such mixture will keep the ability to reduce manifestation of the mentioned neurodegenerations. Test on the issue should be done prior to make a conclusion.

Similarly to Alzheimer disease, caffeine is able to significantly ameliorate a progression of Parkinson disease. Currently, 3 cups of coffee a day are considered as the maximal protective source of caffeine for preventing from Parkinson disease (124). Even Machado-Joseph Disease progression willbe improved by caffeine as well (125). Similarly to Alzheimer disease, the etiology of Parkinson disease is not known and it is hard to propose an effective therapy when it is not clear where to aim the new drugs. Why caffeine is effective in the prevention of Parkinson disease is not known. Maybe anti-neuroinflammation combined with a reduction of neuron's oxidative damage is behind the protective effect (126). Molecular mechanism of such effect is again hardly to be tracked and some pathways can be only hypothesized (32). Nevertheless, caffeine is considered as a perspective compound able to ameliorate neurodegenerative disorders and would serve as the lead structure in pharmacology research on the issue (127). Besidesthe use of caffeine for therapeutic purposes, it was considered as a reagent in a test for diagnosis of Alzheimer disease (128). The test; however, has not become widely used in laboratory praxis so its validity cannot be confirmed.
Owing to neurodegenerative disorders, caffeine does not have a beneficial role only. It is known that caffeine is negatively implicated in the Huntington's disease. Comparing to the aforementioned neurodegenerative disorders, Huntington's disease is genetically determined and typically starts much earlier than Alzheimer or Parkinson disease (129). Caffeine causes earlier onset of Huntington's disease and should be avoided in the individuals with prognosis to the disease $(130,131)$.There are probably more mechanismsof an early onset and progression of Huntington's disease, and they remain misunderstood $(132,133)$. However, molecular mechanism of an early onset of Huntington's disease should be further researched prior to make a simple conclusion. Summarization of caffeine implication in the mentioned neurodegenerations is given in the Table 4 .

\section{Derivatives with caffeine moiety and their use}

Attempts to prepare modified caffeine weremade duringa long time.Invented 8-beta-dimethylaminoethoxycaffeine, 8-beta-dimethyl-aminoethoxycaffeine, 8-beta-diethylaminoethoxycaffeine, 8-beta-diethyl-aminoethoxycaffeine, 8-beta-diethyl-aminoethoxycaffeine and protocols for their synthesis can be mentioned as an early effort to use caffeine (134). However, the simple derivatives of caffeine did not overcome caffeine in the both biological effects and costs and the compounds were not introduced to market as drugs or food supplements. Compounds based on caffeine with broncholitic activity (Fig. 3) were also invented and preclinically tested (135). Caffeine, as well as the other adenosine antagonists, can be used for protection against cardiac ischemia(136). The fact was utilized by Liang and Jacobs who invented caffeine derivatives (Fig. 4) and made basic tests for their efficacy (137). The invented 8-(3-chlorostyryl) caffeine derivatives were used as $\mathrm{A}_{2 \mathrm{~A}}$ adenosine receptor antagonists and the authors depicted the beneficial effect on cell lines. These findings can appear as ridiculous<smiles>[R]c1nc([R])c(C(=O)OC(C)c2nc3c(c(=O)n(C)c(=O)n3C)n2C)c([R])c1[R]</smiles>

where $\mathrm{R}_{1}-\mathrm{R}_{4}$ : hydrogen, chlorine, bromine, an alkyl or an alkoxy group.

Fig. 3. Basic structure of invented caffeine derivatives with broncholitic activity (135).

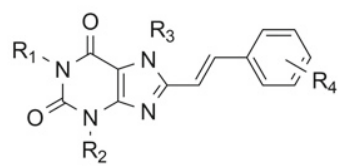

where:

$\mathrm{R}_{1}, \mathrm{R}_{2}$ - methyl, ethyl. propyl, allyl

$\mathrm{R}_{3}-\mathrm{H}$, methyl, alkyl, with 2 - 8 carbons

$\mathrm{R}_{4}-\mathrm{H}, \mathrm{MeO}, \mathrm{NH}_{2}, \mathrm{NO}_{2}, \mathrm{~F}, \mathrm{Cl}$, etc.

Fig.4.Caffeine derivatives for cardiac ischemia treating (137). 
$520-530$

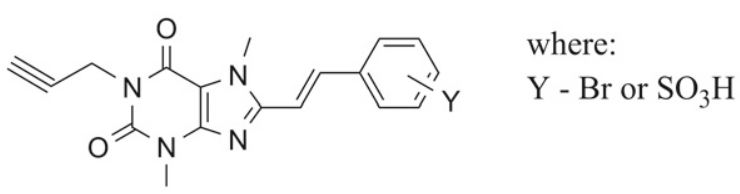

Fig. 5.Selected caffeine derivatives for hepatic fibrosis, cirrhosis and fatty liver formationtreating (141).

because tachycardia resulting from caffeine effect will worsen the ischemia. Caffeine as well as the other compounds antagonizing or agonizing $\mathrm{A}_{2 \mathrm{~A}}$ adenosine receptor have a potential to modulate striatopallidal pathway that represents a link between the cardiovascular system and the brain parenchyma(138-140). Beneficial effect of caffeine and caffeine derived compounds in cardiac ischemia despite of risk of tachycardia can be explained just by the striatopallidal pathway.A group of caffeine derived compounds was also preparedbyCronstein et al (Fig. 5) and the authors proved efficiency of their compounds on in vitro tests(141). The other caffeine containing moiety compounds were preparedin order to use their antagonism on adenosine receptors and other targets structures as well.In an example, Ivatchenko and co-workers invented 2,6-dioxo-2,3,6,7-tetrahydro-1 H-purine-8-ylderived compounds and claimed their potency to be used for disparate purposes in pharmacology (142). Quite similar compounds were prepared by Palle and co-workers (143). The authors claimed that the prepared compounds deserved attention for future research and would be suitable in therapy of asthma, chronic obstructive pulmonary disorder, angiogenesis, pulmonary fibrosis, emphysema, allergic diseases, inflammation, reperfusion injury, myocardial ischemia, atherosclerosis, hypertension, congestive heart failure, retinopathy, diabetes mellitus, obesity, inflammatory gastrointestinal tract disorders, and/or autoimmune diseases. The expected use ishowever, notconfirmed by an extensive test so the compounds should be further researched. Besides the aforementioned, caffeine derivatives were also prepared for e.g. extra-pyramidal syndrome (144) and therapy of Parkinson's disease (145). The all mentioned patents would be promising but more work to characterize prepared compounds should be done.

Modified caffeine moiety can be found in cafedrine and theodrenaline (Fig.6). The compounds are available as e.g. drug Akrinor for treatment of acute hypotension (146,147). The effect of Akrinor is manifested by an increase of cardiac output and venous return. No comparable drugs are available (148). Effect of cafedrine and theodrenaline is mediated via alpha 1 adrenaline receptor, adenosine receptors do not have a role in the effect (149).
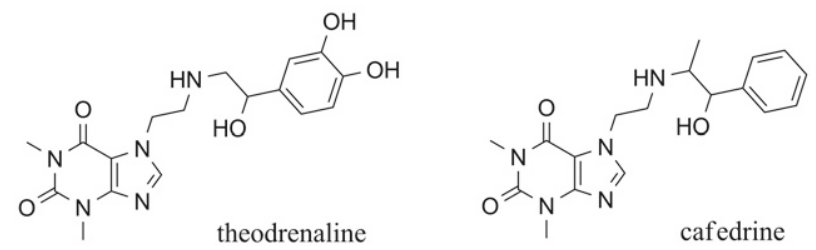

Fig. 6.Structure of cafedrine and theodrenaline.

\section{Conclusion}

Caffeine is a simple compound with a significant effect on the body. Though the major pathways of caffeine are revealed,a lot of mysteries about caffeine remain. Especially the links between caffeine and neuroinflammation as well as neurodegenerative disorders are proved, but not understood in their principles. Nevertheless, promising mixtures of caffeine with other effective substances and/or caffeine derivatives were prepared and published or invented. Practical impact of the findings is expected and the role of caffeine in the pharmacology probably will probably increase in the future.

\section{References}

1. Magalhaes ST, Fernandes FL, Demuner AJ, Picanco MC, Guedes RN.Leaf alkaloids, phenolics, and coffee resistance to the leaf miner leucoptera coffeella (lepidoptera: Lyonetiidae). J Econ Entomol 2010; 103 (4): 1438-1443.

2. Kravchenko LV, Trusov NV, Aksenov IV et al.Effects of green tea extract and its components on antioxidant status and activities of xenobiotic metabolizing enzymes of rats. Vopr Pitan 2011; 80 (2): 9-15.

3. Scoparo CT, de Souza LM, Dartora N, Sassaki GL, Gorin PA, Iacomini M.Analysis of camellia sinensis green and black teas via ultra high performance liquid chromatography assisted by liquid-liquid partition and two-dimensional liquid chromatography (size exclusion $\times$ reversed phase). J Chromatogr A 2012; 1222: 29-37.

4. Greenfield M.When america first met china: An exotic history of tea, drugs, and money in the age of sail. Pac Hist Rev 2013; 82 (4): 626-627.

5. Villavicencio-Enriquez L. Agroforestry characterization in traditional and rustic coffee systems in san miguel, veracruz, mexico Rev Chapingo Ser Cienc For Am 2013; 19 (1): 67-80.

6. Han WY, Xu JM, Wei K, Shi RZ, Ma LF. Soil carbon sequestration, plant nutrients and biological activities affected by organic farming system in tea (camellia sinensis (1. ) o. Kuntze) fields. Soil Sci Plant Nutr 2013; 59 (5): 727-739.

7. Tavares C, Sakata RK.Caffeine in the treatment of pain. Rev Bras Anestesiol 2012; 62 (3): 387-401.

8. Welsh EJ, Bara A, Barley E, Cates CJ.Caffeine for asthma. Cochrane Database Syst Rev 2010; (1).

9. Cauli O, Morelli M.Caffeine and the dopaminergic system. Behav Pharmacol 2005; 16 (2): 63-77.

10. Choung MG, Hwang YS, Lee MS, Lee J, Kang ST, Jun TH. Comparison of extraction and isolation efficiency of catechins and caffeine from green tea leaves using different solvent systems. Int J Food Sci Technol 2014; 49 (6): 1572-1578.

11. Rai A, Punase KD, Mohanty B, Bhargava R.Evaluation of models for supercritical fluid extraction. Int J Heat Mass Transf 2014; 72: 274-287.

12. Kumar GSS, Seethalakshmi PG, Bhuvanesh N, Kumaresan S. Cocrystals of caffeine with formylphenoxyaliphatic acids: Syntheses, structural characterization, and biological activity. J Mol Struct 2013; 1034: 302-309.

13. Rivara S, Piersanti G, Bartoccini F et al.Synthesis of (e)-8-(3-chlorostyryl)caffeine analogues leading to 9-deazaxanthine derivatives as dual a(2a) antagonists/mao-b inhibitors. J Med Chem 2013; 56 (3): 1247-1261. 
14. Cordell GA.Fifty years of alkaloid biosynthesis in phytochemistry. Phytochemistry 2013; 91: 29-51.

15. Ashihara H, Sano H, Crozier A. Caffeine and related purine alkaloids: Biosynthesis, catabolism, function and genetic engineering. Phytochemistry 2008; 69 (4): 841-856.

16. McCarthy AA, McCarthy JG.The structure of two n-methyltransferases from the caffeine biosynthetic pathway. Plant Physiol 2007; 144 (2): 879-889.

17. Negishi O, Ozawa T, Imagawa H.N-methyl nucleosidase from tea leaves Agric Biol Chem1988; 52 (1): 169-175.

18. Koshiishi C, Kato A, Yama S, Crozier A, Ashihara H. A new caffeine biosynthetic pathway in tea leaves: Utilisation of adenosine released from the s-adenosyl-1-methionine cycle. FEBS Lett 2001; 499 (1-2): 50-54.

19. Kato M, Mizuno K.Caffeine synthase and related methyltransferases in plants. Front Biosci 2004; 9: 1833-1842.

20. Skinner TL, Jenkins DG, Folling J, Leveritt MD, Coombes JS, Taaffe DR.Influence of carbohydrate on serum caffeine concentrations following caffeine ingestion. J Sci Med Sport 2013; 16 (4): 343-347.

21. Mesaros C, Culea M, Iordache AM, Visovan I, Cozar C, Cosma C.A new caffeine test for diagnosis of cirrhosis by $\mathrm{gc} / \mathrm{ms}$. Asian J Chem 2010; 22 (5): 3608-3614.

22. Orru M, Guitart X, Karcz-Kubicha $M$ et al.Psychostimulant pharmacological profile of paraxanthine, the main metabolite of caffeine in humans. Neuropharmacology 2013; 67: 476-484.

23. Seng KY, Fun CY, Law YL, Lim WM, Fan W, Lim CL.Population pharmacokinetics of caffeine in healthy male adults using mixed-effects models. J Clin Pharm Ther 2009; 34 (1): 103-114.

24. Bannnister AJ, Schneider R, Kouzarides T. Histone methylation: Dynamic or static? Cell 2002; 109 (7): 801-806.

25. Yubero-Lahoz S, Pardo R, Farre M et al. Changes in cypla2 activity in humans after 3, 4-methylenedioxymethamphetamine (mdma, ecstasy) administration using caffeine as a probe drug. Drug Metab Pharmacok 2012; 27 (6): 605-613.

26. Tanaka S, Uchida S, Inui N, Takeuchi K, Watanabe H, Namiki N.Simultaneous lc-ms/ms analysis of the plasma concentrations of a cocktail of 5 cytochrome $\mathrm{p} 450$ substrate drugs and their metabolites. Biol Pharm Bull 2014; 37 (1): 18-25.

27. Ghotbi R, Christensen M, Roh HK, Ingelman-Sundberg M, Aklillu E, Bertilsson L. Comparisons of cyp1a2 genetic polymorphisms, enzyme activity and the genotype-phenotype relationship in swedes and koreans. Eur J Clin Pharmacol 2007; 63 (6): 537-546.

28. Wang L, Hu Z, Deng X, Wang Y, Zhang Z, Cheng ZH. Association between common cyp1a2 polymorphisms and theophylline metabolism in non-smoking healthy volunteers. Basic Clin Pharmacol Toxicol 2013; 112 (4): 257-263.

29. Kot M, Daniel WA.Caffeine as a marker substrate for testing cytochrome p450 activity in human and rat. Pharmacol Rep 2008; 60 (6): 789-797.

30. Gordillo-Bastidas D, Oceguera-Contreras E, Salazar-Montes A, Gonzalez-Cuevas J, Hernandez-Ortega LD, Armendariz-Borunda J.Nrf2 and snail-1 in the prevention of experimental liver fibrosis by caffeine. World J Gastroenterol 2013; 19 (47): 9020-9033.

31. Machado SR, Parise ER, Carvalho L.Coffee has hepatoprotective benefits in brazilian patients with chronic hepatitis $\mathrm{c}$ even in lower daily consumption than in american and European populations. Braz J Infect Dis 2014; 18 (2): $170-176$.

32. Pohanka M.The effects of caffeine on the cholinergic system. Mini Rev Med Chem 2014; 16 (6): 543-549.

33. Namuslu M, Kocaoglu H, Celik HT et al.Effects of aqueous soybean, mistletoe and red clover extracts on activities of adenosine deaminase and xanthine oxidase enzyme. Brat Med J 2014; 115 (6): 367-371.

34. Gyoneva S, Shapiro L, Lazo C et al.Adenosine a(2a) receptor antagonism reverses inflammation-induced impairment of microglial process extension in a model of parkinson's disease. Neurobiol Dis 2014; 67: 191-202.

35. Vincenzi F, Targa M, Romagnoli R et al. Trr469, a potent a(1) adenosine receptor allosteric modulator, exhibits anti-nociceptive properties in acute and neuropathic pain models in mice. Neuropharmacology 2014; 81: 6-14.

36. Hofer M, Pospisil M, Dusek L, Hoferova Z, Komurkova D.Combined pharmacological therapy of the acute radiation disease using a cyclooxygenase-2 inhibitor and an adenosine a(3) receptor agonist. Cent Eur J Biol 2014; 9 (6): 642-646.

37. Fukunaga AF, Alexander GE, Stark CW.Characterization of the analgesic actions of adenosine: Comparison of adenosine and remifentanil infusions in patients undergoing major surgical procedures. Pain 2003; 101 (1-2): 129-138.

38. Joulia F, Coulange $\mathbf{M}$, Lemaitre $\mathbf{F}$ et al.Plasma adenosine release is associated with bradycardia and transient loss of consciousness during experimental breath-hold diving. Int J Cardiol 2013; 168 (5): E138-E141.

39. Sullivan GW, Luong LS, Carper HT, Barnes RC, Mandell GL. Methylxanthines with adenosine alter tnf-alpha-primed pmn activation. Immunopharmacology1995; 31 (1): 19-29.

40. Chan ESL, Fernandez P, Cronstein BN.Adenosine in inflammatory joint diseases. Purinergic Signal 2007; 3 (1-2): 145-152.

41. Wei CJ, Augusto E, Gomes CA et al. Regulation of fear responses by striatal and extrastriatal adenosine a(2a) receptors in forebrain. Biol Psychiatry 2014; 75 (11): 855-863.

42. Tavares AAD, Batis J, Barret $\mathrm{O}$ et al.In vivo evaluation of i-123 mni420: A novel single photon emission computed tomography radiotracer for imaging of adenosine2a receptors in brain. Nucl Med Biol 2013; 40 (3): 403-409.

43. Saki M, Yamada K, Koshimura E, Sasaki K, Kanda T.In vitro pharmacological profile of the a(2a) receptor antagonist istradefylline. NaunynSchmiedebergs Arch Pharmacol 2013; 386 (11): 963-972.

44. Samsonsen C, Brathen G, Reimers A, Helde G, Brodtkorb E.Is dietary caffeine involved in seizure precipitation? Epilepsy Behav 2013; 28 (2): $147-150$.

45. Fronz U, Deten A, Baumann $\mathbf{F}$ et al.Continuous adenosine a(2a) receptor antagonism after focal cerebral ischemia in spontaneously hypertensive rats. Naunyn-Schmiedebergs Arch Pharmacol 2014; 387 (2): $165-173$.

46. Walaschewski R, Begrow F, Verspohl EJ. Impact and benefit of a2badenosine receptor agonists for the respiratory tract: Mucociliary clearance, ciliary beat frequency, trachea muscle tonus and cytokine release. J Pharm Pharmacol 2013; 65 (1): 123-132.

47. Hayallah AM, Elgaher WA, Salem OI, Alim A. Design and synthesis of some new theophylline derivatives with bronchodilator and antibacterial activities. Arch Pharm Res 2011; 34 (1): 3-21. 


\section{$520-530$}

48. VanHaitsma TA, Mickleborough T, Stager JM, Koceja DM, Lindley MR, Chapman R. Comparative effects of caffeine and albuterol on the bronchoconstrictor response to exercise in asthmatic athletes. Int J Sports Med 2010; 31 (4): 231-236.

49. Alafeefy AM, Alqasoumi SI, Hamid SGA et al.Synthesis and hypoglycemic activity of some new theophylline derivatives. J Enzym Inhib Med Chem 2014; 29 (3): 443-448.

50. Gibson CM, Fowler PW.Aromaticity of caffeine, xanthine and the dimethyl xanthines. Tetrahedron Lett 2014; 55 (13): 2078-2081.

51. Swift B, McGinn R, Gagnon D, Crandall CG, Kenny GP. Adenosine receptor inhibition attenuates the decrease in cutaneous vascular conductance during whole-body cooling from hyperthermia. Exp Physiol 2014; 99 (1): 196-204

52. Szadujkis-Szadurska K, Grzesk G, Szadujkis-Szadurski L, Gajdus M, Matusiak G. Role of acetylcholine and calcium ions in three vascular contraction models: Angiotensin ii, phenylephrine and caffeine. Exp Ther Med 2012; 4 (2): 329-333.

53. Glatter KA, Myers R, Chiamvimonvat N.Recommendations regarding dietary intake and caffeine and alcohol consumption in patients with cardiac arrhythmias: What do you tell your patients to do or not to do? Curr Threat Options Cardiovasc Med 2012; 14 (5): 529-535.

54. Cummings KJ, Commons KG, Trachtenberg FL, Li A, Kinney HC, Nattie EE.Caffeine improves the ability of serotonin-deficient (pet1-/-) mice to survive episodic asphyxia. Pediatr Res 2013; 73 (1): 38-45.

55. Golembiowska K, Dziubina A.The effect of adenosine a(2a) receptor antagonists on hydroxyl radical, dopamine, and glutamate in the striatum of rats with altered function of vmat2. Neurotox Res 2012; 22 (2): $150-157$.

56. Shin HJ, Ryu JH, Kim ST, Zuo Z, Do SH. Caffeine-induced inhibition of the activity of glutamate transporter type 3 expressed in xenopus oocytes. Toxicol Lett 2013; 217 (2): 143-148.

57. Petzer A, Pienaar A, Petzer JP. The interactions of caffeine with monoamine oxidase. Life Sci 2013; 93 (7): 283-287.

58. Petzer A, Grobler P, Bergh JJ, Petzer JP. Inhibition of monoamine oxidase by selected phenylalkylcaffeine analogues. J Pharm Pharmacol 2014; 66 (5): 677-687.

59. Pohanka M, Dobes P.Caffeine inhibits acetylcholinesterase, but not butyrylcholinesterase. Int J Mol Sci 2013; 14: 9873-9882.

60. Pohanka M.Cholinesterases, a target of pharmacology and toxicology. Biomed Pap 2011; 155 (3): 219-229.

61. Pohanka M.Alpha 7 nicotinic acetylcholine receptor is a target in pharmacology and toxicology. Int J Mol Sci 2012; 13 (2): 2219-2238.

62. Pohanka M.Inhibitors of acetylcholinesterase and butyrylcholinesterase meet immunity. Int J Mol Sci 2014; 15 (6): 9809-9825.

63. Pohanka M.Butyrylcholinesterase as a biochemical marker, a review. Brat Med J 2013; 114 (12): 726-734.

64. Herman A, Herman AP. Caffeine's mechanisms of action and its cosmetic use. Skin Pharmacol Physiol 2013; 26 (1): 8-14.

65. Bhaskara S, Chandrasekharan MB, Ganguly R. Caffeine induction of cyp6a 2 and cyp6a 8 genes of drosophila melanogaster is modulated by camp and d-jun protein levels. Gene 2008; 415 (1-2): 49-59.

66. Puttachary S, Robertson AP, Clark CL, Martin RJ.Levamisole and ryanodine receptors. Ii: An electrophysiological study in ascaris suum. Mol Biochem Parasitol 2010; 171 (1): 8-16.
67. Gerasimova EV, Yakovleva OV, Zefirov AL, Sitdikova GF. Role of ryanodine receptors in the effects of hydrogen sulfide on transmitter release from the frog motor nerve ending. Bull Exp Biol Med 2013; 155 (1): 11-13.

68. Gaburjakova J, Gaburjakova M.Coupled gating modifies the regulation of cardiac ryanodine receptors by luminal $\mathrm{ca}(2+)$. Biochim Biophys Acta 2014; 1838 (3): 867-873.

69. Skiteva OI, Lapteva VI, Balezina OP.Role of stored calcium in the regulation of neurotransmitter quantum size. Bull Exp Biol Med 2012; 152 (4): 392-396.

70. Hotta S, Morimura K, Ohya S, Muraki K, Takeshima H, Imaizumi Y.Ryanodine receptor type2 deficiency changes excitation-contraction coupling and membrane potential in urinary bladder smooth muscle. J Physiol 2007; 582 (Pt 2): 489-506.

71. Arnaiz-Cot JJ, Damon BJ, Zhang XH et al. Cardiac calcium signalling pathologies associated with defective calmodulin regulation of type 2 ryanodine receptor. J Physiol-London 2013; 591 (17): 4287-4299.

72. Shou QY, Pan SZ, Tu J et al.Modulation effect of smilax glabra flavonoids on ryanodine receptor mediated intracellular ca2+ release in cardiomyoblast cells. J Ethnopharmacol 2013; 150 (1): 389-392.

73. Friedrich O, Yi B, Edwards JN et al. IL-1 alpha reversibly inhibits skeletal muscle ryanodine receptor a novel mechanism for critical illness myopathy? Am J Respir Cell Mol Biol 2014; 50 (6): 1096-1106.

74. Soner BC, Murat N, Guven H, Gidener S. The role of calcium entry on the relaxation response of rho-kinase inhibitor in rabbit renal artery. Brat Med J 2013; 114 (5): 258-261.

75. Ceraets L, Moonen HJ, Wouters EF, Bast A, Hageman GJ.Caffeine metabolites are inhibitors of the nuclear enzyme poly(adp-ribose)polymerase-1 at physiological concentrations. Biochem Pharmacol 2006; 72 (7): 902-910.

76. Chen JC, Hwang JH, Chiu WH, Chan YC. Tetrandrine and caffeine modulated cell cycle and increased glioma cell death via caspase-dependent and caspase-independent apoptosis pathways. Nutr Cancer 2014; 66 (4): 700-706.

77. Kumala S, Fujarewicz K, Jayaraju D, Rzeszowska-Wolny J, Hancock R. Repair of DNA strand breaks in a minichromosome in vivo: Kinetics, modeling, and effects of inhibitors. PLoS One 2013; 8 (1): e52966.

78. Gervasini G, Ghotbi R, Aklillu E et al. Haplotypes in the 5'-untranslated region of the cyp1a2 gene are inversely associated with lung cancer risk but do not correlate with caffeine metabolism. Environ Mol Mutagen 2013; 54 (2): 124-132.

79. Woziwodzka A, Gwizdek-Wisniewska A, Piosik J. Caffeine, pentoxifylline and theophylline form stacking complexes with iq-type heterocyclic aromatic amines. Bioorg Chem 2011; 39 (1): 10-17.

80. Osowski A, Pietrzak M, Wieczorek Z, Wieczorek J. Natural compounds in the human diet and their ability to bind mutagens prevents DNA-mutagen intercalation. J Toxicol Environ Health A 2010; 73 (1718): 1141-1149.

81. Vukcevic NP, Babic G, Segrt Z, Ercegovic GV, Jankovic S, Acimovic $\mathbf{L}$. Severe acute caffeine poisoning due to intradermal injections: Mesotherapy hazard. Vojnosanit Pregl 2012; 69 (8): 707-713.

82. Vukcevic NP, Babic G, Segrt Z, Ercegovic GV, Jankovic S, Acimovic $\mathbf{L}$. Severe acute caffeine poisoning due to intradermal injections: Mesotherapy hazard (vol 69, pg 707, 2012). Vojnosanit Pregl 2012; 69 (10): 929-929. 
83. Banerjee P, Ali Z, Levine B, Fowler DR. Fatal caffeine intoxication: A series of eight cases from 1999 to 2009. J Forensic Sci 2014; 59 (3): 865-868.

84. Jabbar SB, Hanly MG.Fatal caffeine overdose a case report and review of literature. Am J Forensic Med Pathol 2013; 34 (4): 321-324.

85. Sereshti H, Samadi S. A rapid and simple determination of caffeine in teas, coffees and eight beverages. Food Chem 2014; 158: 8-13.

86. Warszawski D, Gorodischer R, Kaplanski J.Comparative toxicity of caffeine and aminophylline (theophylline ethylenediamine) in young and adult rats. Biol Neonate 1978; 34 (1-2): 68-71.

87. Tawde SN, Pushner B, Albin T, Stump S, Poppenga RH.Death by caffeine: Presumptive malicious poisoning of a dog by incorporation in ground meat. J Med Toxicol 2012; 8 (4): 436-440.

88. Moore MT, Greenway SL, FArris JL, Guerra B.Assessing caffeine as an emerging environmental concern using conventional approaches. Arch Environ Contam Toxicol 2008; 54 (1): 31-35.

89. Seifert SM, Seifert SA, Schaechter JL et al.An analysis of energydrink toxicity in the national poison data system. Clin Toxicol (Phila) 2013; 51 (7): 566-574.

90. Rodriguez RS, Haugen R, Rueber A, Huang CC. Reversible neuronal and muscular toxicity of caffeine in developing vertebrates. Comp Biochem Physiol C-Toxicol Pharmacol 2014; 163: 47-54.

91. Yeh CH, Liao YF, Chang CY et al. Caffeine treatment disturbs the angiogenesis of zebrafish embryos. Drug Chem Toxicol 2012; 35 (4): $361-365$.

92. Tan Y, Liu J, Deng Y et al. Caffeine-induced fetal rat over-exposure to maternal glucocorticoid and histone methylation of liver igf-1 might cause skeletal growth retardation. Toxicol Lett 2012; 214 (3): 279-287.

93. Nikoui V, Ostadhadi S, Takzare N, Nabavi SM, Giorgi M, Bakhtiarian $\mathrm{A}$. The role of clomipramine in potentiating the teratogenic effects of caffeine in pregnant rats: A histopathological study. ScientificWoldJournal 2013; 2013: 382434.

94. Stanton CK, Gray RH. Effects of caffeine consumption on delayed conception. Am J Epidemiol1995; 142 (12): 1322-1329.

95. Kuczkowski KM.Caffeine in pregnancy. Arch Gynecol Obstet 2009; 280 (5): 695-698.

96. Jahanfar S, Jaafar SH.Effects of restricted caffeine intake by mother on fetal, neonatal and pregnancy outcome. Cochrane Database Syst Rev 2013; 2: CD006965.

97. Chavarro JE, Rich-Edwards JW, Rosner BA, Willett WC.Caffeinated and alcoholic beverage intake in relation to ovulatory disorder infertility. Epidemiology 2009; 20 (3): 374-381.

98. Sharma R, Biedenharn KR, Fedor JM, Agarwal A. Lifestyle factors and reproductive health: Taking control of your fertility. Reprod Biol Endocrinol 2013; 11: 66.

99. Tournaye HJ, Cohlen BJ. Management of male-factor infertility. Best Pract Res Clin Obstet Gynaecol 2012; 26 (6): 769775.

100. Homan G, Litt J, Norman RJ. The fast study: Fertility assessment and advice targeting lifestyle choices and behaviours: A pilot study. Hum Reprod 2012; 27 (8): 2396-2404.

101. Yamaguchi S, Funahashi H, Murakami T.Improved fertility in gilts and sows after artificial insemination of frozen-thawed boar semen by supplementation of semen extender with caffeine and cacl2. J Reprod Dev 2009; 55 (6): 645-649.
102. Nehlig A.Is caffeine a cognitive enhancer? J Alzheimer Dis 2010; 20 (Supp11): S85-94.

103. Lachance MP.The pharmacology and toxicology of caffeine. J Food Safe1982; 4 (2): 71-112.

104. Porciuncula LO, Sallaberry C, Mioranzza S, Botton PH, Rosemberg DB. The janus face of caffeine. Neurochem Int 2013; 63 (6): 594-609.

105. Chu YF, Chang WH, Black RM et al.Crude caffeine reduces memory impairment and amyloid beta(1-42) levels in an alzheimer's mouse model. Food Chem 2012; 135 (3): 2095-2102.

106. Vila-Luna S, Cabrera-Isidoro S, Vila-Luna $L$ et al. Chronic caffeine consumption prevents cognitive decline from young to middle age in rats, and is associated with increased length, branching, and spine density of basal dendrities in cal hippocampal neurons Neuroscience 2012; 202: 384-395.

107. Pohanka M.Alzheimer's disease and oxidative stress. A review. Curr Med Chem 2013; 21 (3): 356-364.

108. Rivera-Oliver M, Diaz-Rios M. Using caffeine and other adenosine receptor antagonists and agonists as therapeutic tools against neurodegenerative diseases: A review. Life Sci 2014; 101 (1-2): 1-9.

109. Knight JR.Remedy for migraine headache. Ca2826019 a1.2012.

110. Destrebecq A, Terzoni S, Sala E. Post-lumbar puncture headache: A review of issues for nursing practice. J Neurosci Nurs 2014; 46 (3): 180-186.

111. Duff M, Elkhodair S.Caffeine in the treatment of post lumbar puncture headache. Emerg Med J 2010; 27 (6): 477-477.

112. Elkhodair S, Duff M. Caffeine in the prophylaxis of post lumbar puncture headache Emerg Med J 2010; 27 (6): 476-477.

113. Grasela J, Schupp J, Nacht S. Anti-cellulite composition and method of treating cellulite. Us 2013/0 210840 a1. 2013.

114. Doherty J, Apong P, Akrong J, Shirazi S. Compositions and methods for promoting weight loss and increasing energy. Ca2747904 a1.2012.

115. Eskelinen MH, Kivipelto M. Caffeine as a protective factor in dementia and alzheimer's disease. J Alzheimer Dis 2010; 20 (S1): 167-174.

116. Chu YF, Chen Y, Brown PH, Lyle BJ. Coffee extracts as ingredients of foods, drugs, cosmetics, dietary supplements, and biologics. Us 2013/0261136 a1.2013.

117. Hirsbrunner P, Pavillard B.Purification of caffeine; us4758662. 1988.

118. Bailey DT, Yuhasz RL, Zheng B.Method for isolation of caffeinefree catechins from green tea; us6210679b1. 2001.

119. Roselius L, Kurzhais HA, Hubert P. Method for the selective extraction of caffeine from vegeable materials; us4 255458. 1981.

120. Ogura Y, Ohishi S, Fukuda M, Takahashi H, Itaya E, Konishi A. Method for removing caffeine from caffeine-containing catechin compound composition; us 2014/0113011a1. 2014.

121. International FB, Caffeine electronic cigarette liquid. Cn 101926505 a. 2010 .

122. Chauffard F, Enslen MYA, Tachon P. Sustained release microparticulate caffeine formulation; us 5700484 a. 1997.

123. Crain S, Crain WW, Crain SM, Crain M.Novel method to improve the safety and efficacy of caffeine. Us 20130197015 a1. 2013.

124. Qi H, Li SX.Dose-response meta-analysis on coffee, tea and caffeine consumption with risk of parkinson's disease. Geriatr Gerontol Int 2014; 14 (2): 430-439. 


\section{$520-530$}

125. Concalves N, Simoes AT, Cunha RA, Almeida LP. Caffeine and adenosine $\mathrm{a}(2 \mathrm{a})$ receptor inactivation decrease striatal neuropathology in a lentiviral-based model of machado-joseph disease. Ann Neurol 2013; 73 (5): 655-666.

126. Golembiowska K, Wardas J, Noworyta-Sokolowska K, Kaminska K, Gorska A.Effects of adenosine receptor antagonists on the in vivo lps-induced inflammation model of parkinson's disease. Neurotox Res 2013; 24 (1): 29-40.

127. Payami H, Factor SA.Promise of pharmacogenomics for drug discovery, treatment and prevention of parkinson's disease. A perspective. Neurotherapeutics 2014; 11 (1): 111-116.

128. Sandford-Mifflin KK, Parshad R, Robbins JH. Irradiating cell culture with florescent light; adding caffeine; incubation; us573219a. 1998.

129. Kobal J, Melik Z, Cankar K, Strucl M. Cognitive and autonomic dysfunction in presymptomatic and early huntington's disease. J Neurol 2014; 261 (6): 1119-1125.

130. Simonin C, Duru C, Salleron J et al. Association between caffeine intake and age at onset in huntington's disease. Neurobiol Dis 2013; 58: $179-182$.

131. Duru C, Simonin C, Richard F et al.Caffeine is a modifier of age at onset in huntington's disease. Mov Disord 2011; 26 (Suppl 2): S60-S61.

132. Marangoni M, Adalbert R, Janeckova L et al. Age-related axonal swellings precede other neuropathological hallmarks in a knock-in mouse model of huntington's disease. Neurobiol Aging 2014; 35 (10): 2382-2393.

133. Koutsis G, Karadima G, Kladi A, Panas M.Late-onset huntington's disease: Diagnostic and prognostic considerations. Parkinsonism Relat Disord 2014; 20 (7): 726-730.

134. Copper DE, Cheney LC. Basic caffeine derivatives; us 2688618. 1952.

135. Arcari G, Micheli P, Luini F, Scarponi U.Caffeine derivatives; us3975389. 1976.

136. Jimenez-Botello LC, Avila-Costa MR, Carillo-Ruiz JD, CorreaBasurto J, Picazo O, Querejeta-Villagomez E. Therapeutic potential of caffeine derivate 1-methylxanthine, as a2a adenosine receptor antagonist on striatopallidal pathway. Mov Disord 2010; 25: S636-S636.

137. Liang BT, Jacobson KA.Methods for protecting against cardiac ischemia by administering adenosine a2a receptor antagonists; us5859019. 1999.
138. Higley MJ, Sabatini BL.Competitive regulation of synaptic ca2+ influx by $\mathrm{d} 2$ dopamine and a 2 a adenosine receptors. Nat Neurosci 2010; 13 (8): 958-U977.

139. Tanimura Y, Vaziri S, Lewis MH. Indirect basal ganglia pathway mediation of repetitive behavior: Attenuation by adenosine receptor agonists. Behav Brain Res 2010; 210 (1): 116-122.

140. Lazarus M, Shen HY, Cherasse $Y$ et al.Arousal effect of caffeine depends on adenosine $\mathrm{a}(2 \mathrm{a})$ receptors in the shell of the nucleus accumbens. The Journal of neuroscience : the official journal of the Society for Neuroscience 2011; 31 (27): 10067-10075.

141. Cronstein BN, Chan E.Adenosine a2a receptor antagonists for treating and preventing hepatic fibrosis, cirrhosis and fatty liver; us 6555545 b2. 2003 .

142. Ivachtchenko AV, Mitkin OD, Kadieva MG, M. OI. Substituted phenoxyacetic acids and esters and amides thereof, comprising a2, 6-dioxo-2, 3, 6, 7-tetrahydro-1H-purine-8-yl fragment and constituting a2a adenosine receptor antagonists, and the use thereof; wo 2013058681a3. 2012.

143. Palle V, Ramadas V, Barawkar D et al.Substituted fused pyrimidine compounds; wo2010103547 a2.2010.

144. Grzelak M, Hunter JC, Pond A, Varty G. Adenosine a2a receptor antagonists for the treatemnt of extra-pyramidal syndrome and other movement disorders; wo2007038212a1.2007.

145. Suzuki F, Shimada J, Koike $\mathbf{N}$ et al. Therapeutic agents for parkinson's disease; ep0590919a1. 1993.

146. Clemens KE, Quednau I, Heller AR, Klaschik E. Impact of cafedrine/theodrenaline (akrinor ${ }^{\circledR}$ ) on therapy of maternal hypotension during spinal anesthesia for cesarean delivery: A retrospective study. Minerva Ginecol 2010; 62 (6): 515-524.

147. Strumper D, Gogarten W, Durieux ME, Hartleb K, Van Aken H, Marcus MA. Effects of cafedrine/theodrenaline, etilefrine and ephedrine on uterine blood flow during epidural-induced hypotension in pregnant sheep. Fetal Diagn Ther 2005; 20 (5): 377-382.

148. Koch T, Wenzel V. Old drugs and new approval procedures: Akrinor remains marketable and an application for reapproval of arginin vasopressin has been made. Anaesthesist 2006; 55 (6): 708-710.

149. Uschenko T, Foellner S, Gruendling $M$ et al. Akrinor-induced relaxation of pig coronary artery in vitro is transformed into alpha1-adrenoreceptor-mediated contraction by pretreatment with propranolol. J Cardiovasc Pharmacol 2006; 47 (3): 450-455.

Received October 4, 2014. Accepted October 22, 2014. 